\title{
Islamic Education Perspective
}

\section{Adi Kasman}

STAIN Tengku Dirundeng Meulaboh

adi_payalumpat@yahoo.co.id

\begin{abstract}
Islamic studies is a learning material that is studied and studied by students of high Islamic colleges, is also one component of general courses that must be followed by all of them in all the faculties and all the majors, which also covered a wide range of Islamic sciences, both of which dealing with the law, education, history, thoughts in Islam, even studied about the different kinds of approach in understanding the religion, the source of the teachings, the characteristic teachings of Islam itself, and the methodology of understanding about Islam in a comprehensive manner with diversity theory combined with model or type of research. Such approaches include a "normative theological, anthropological, sociological, psychological, historical, cultural, and philosophical approaches".
\end{abstract}

Keywords

perspective; studies, Islam



\section{Introduction}

God's Word:

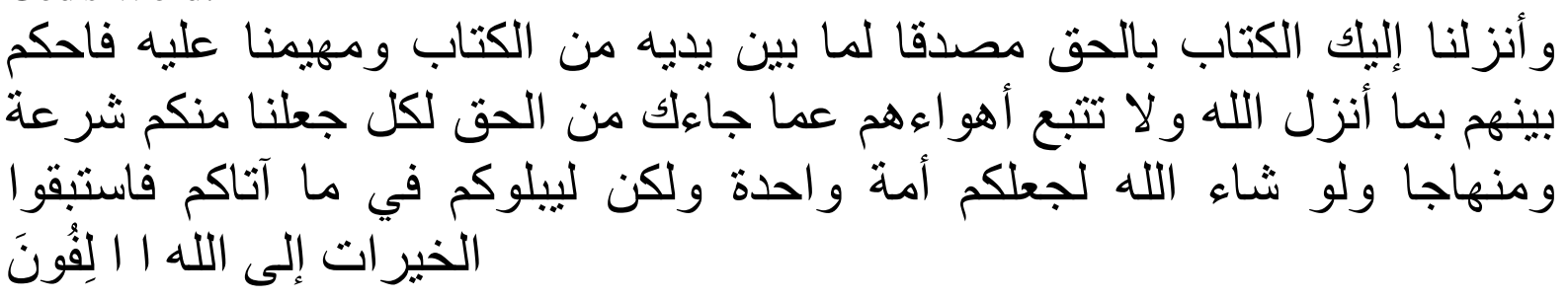

"And We (God) sent down to you (Muhammad) the holy book (Al-Quran) as a support for the truth of the scriptures that existed before, and to support the holy book. So carry out the law (teaching of goodness) between them according to what Allah revealed, and do not follow their desires away from the truth that has come to you. For each of you (humanity) we make shari'ah (path to truth) and minhaj (method of implementation). If Allah had willed He would have made you (humanity) into a single people. But (made of various kinds) so that He may test you all regarding the things (paths and methods) that have been given to you. So race you all towards goodness. And only to Allah is your return. (Qur'an 5:48)

Approach and the methodology carried out aims to provide understanding to students, so that later they can truly understand the implementation of the practice of Islamic teachings in the world of education which has been, is and will develop in the midst of a pluralistic society. With various styles, patterns of understanding, and practice of the Islamic sciences that they understand. The demand for understanding the methodology of Islamic education for students is essentially also a provision to conduct studies and research methodologies for Islamic education studies in a measurable and independent manner. This is as stated by Abuddin Nata that the methodology of Islamic studies seeks to describe in general the scope of Islamic teachings also suggests various methods and approaches that can be used to 
produce a comprehensive understanding of Islam. His opinion illustrates that Islamic studies are only directed at graduates in an Islamic educational institution only to memorize its teachings, but they are not able to develop it, both in terms of psychomotor, cognitive and affective. In this case, Imam al-Ghazali commented: All humans will perish, except for those who have knowledge. Everyone who has knowledge will perish, except those who do good deeds. All those who do good deeds will also perish, except those who are sincere and honest (in al-Abrasyi, 1987: 46)

Imam al-Ghazali's statement requires that every Muslim wants to learn, then do charity, act and work with the knowledge he has, sincere and full of honesty values in all actions and deeds. Because it has no meaning and meaning in front of Allah swt if it is not based on the values of faith or the true faith.

Therefore, it is expected that students must be able to study and conduct various kinds of studies and research on the development of Islam that is developing in the midst of a pluralistic and modern society today, because a Muslim is required to really understand, and have comprehensive and integral insights that related to all sources of Islamic teachings, so that they can respond to all the actual problems that occur in people's lives.

\section{Review of Literature}

What is meant by "religion?" How to define "Islamic religion?" Various interpretations of the meaning of religion One of them is that it is not chaotic, religious people are not confused. Others say that religion is a path that leads a person to happiness. But no matter how different they are, once again we find their differences when discussing what the nature of religion is. One of the oldest definitions of the nature of religiosity that many religious scholars would accept is that religiosity or religion is one's attempt to imitate the attributes of the God he believes in, acknowledging that there is an all-powerful power above his power (supernatural) which in anthropological terms is called supernatural beings emulate him according to his ability as a human. A Muslim when fasting, for example, is essentially trying to imitate the attributes of Allah. Who do not eat, do not drink?

Meanwhile, Islam is a religion that teaches according to human nature, both in terms of faith, shari'ah, worship, muamalah and so on. Allah commands humans to face and enter the religion of nature. Allah swt said. "So turn your face straight to the religion (Islam); (according to) the nature of Allah which He has created man according to (fitrah). There is no change in Allah's creation. (That is) the straight religion, but most people do not know." "Enter all of you into Islam as a whole". This shows that humans in carrying out various activities must be truly Islamic, faith, sharia, worship, muamalah, and so on. Prophet Muhammad SAW said: "No baby is born except in a state of fitrah, so it is his parents who make him a Jew. "The existence of religious potential contained in humans can also be analyzed from the term human being used by the Qur'an to denote humans". Humans are limited in their abilities, therefore it is impossible for Allah SWT who has created humans, then $\mathrm{He}$ gives burdens to His servants what they are not able to bear.

In terms of language, the meaning of Islam comes from the Arabic language, namely salima which means safe, peaceful, and peaceful. Then from the word salima it changes to the form of aslama which means surrender to enter peace. Quraish Shihab said the meaning of "Islam is submission". is a religion that believes in only one God, namely Allah. This religion belongs to the heavenly religion (a religion that is believed by its followers to be sent down from the sky) and belongs to the Abrahamic religion. With more than one and a quarter billion followers around the world, making Islam a religion that is widely practiced on this earth. Followers of Islam are known as Muslims and Muslimat. It means people who give up. 
Islam teaches that Allah revealed His word to mankind through His messengers, and it is firmly believed that Prophet Muhammad SAW. is the last prophet and messenger sent into the world by Allah, and His servants (the people of the Prophet Muhammad) are the best people, taught to always invite to good and prevent all evil for himself, his family, and society in general, He says: You are the best people who were born for humans, enjoining the righteous, and forbidding the evil, and believing in Allah. If the people of the Book had believed, it would have been better for them, among them there are believers, and most of them are ungodly (Qur'an 2:110).

Islam or al-Islam, also means "submission and submission to God who covers the entire universe - this universal al-Islam is the only teaching that provides guidance on submission or deen which is justified by God Almighty". Thus, the meaning of Islam is submission, obedience and submission in all actions and actions of all human beings must be truly in accordance with the intent and purpose of Allah creating creatures whose names are humans, namely serving, worshiping solely because and for all of them.

Al-Quran is a revelation by Allah to the Prophet Muhammad through the Angel Jibreel, to be conveyed to Muslims, and the Al-Qur'an is as a guide and rule of life for Muslims that are historical and normative. Not all of the verses of the Al-Qur'an that are historical and normative can be understood only textually, because many of the verses of the Al-Qur'an still have broad (universal) meanings and need to be interpreted deeper, so that a law or wisdom that can be understood and practiced by all humans in general and Muslims in particular. (Hasbullah et al, 2019)

\section{Discussion}

Since a long time, Islam has been studied more and more by people, Muslims and nonMuslims alike. What are the motivations for this phenomenon to become so prominent, especially after the 1970s? As it is known, that the state of Indonesia is not an Islamic state, Islam cannot be separated from the state, but a democratic country based on Pancasila and the 1945 Constitution. Thus, the people adhere to various religions and beliefs according to their respective beliefs, both Muslim and non-Muslim. . It is an undeniable fact that throughout the 1970s, 1980s, and 1990s, Indonesia has recorded a very progressive and future Islamic revival. This is an extraordinary and surprising phenomenon,

A number of studies, both in terms of academic assignments and other scientific researches, explain the development of Islamic thought in Indonesia and its characters. These developments of thought are generally referred to as the horizon of Islamic modernization in Indonesia and the emergence of "Modernist Islam". In the book Traces of Thought from Renewal to Guru Bangsa, a national reformer, Nurcholish Madjid, as Cak Nur is called, many people see him as a figure who presents the "new Muhammad Natsir", a cleric, intellectual and reformist political figure who is prohibited from participating in the political arena. politics by the rulers. But after 1970, Nurcholish Madjid with his HMI which he influenced, he expressed his ideas for renewal, namely shortly after returning from his first trip to Europe, America and the Middle East. This means that Nurcholish Madjid has seen unfavorable symptoms for Muslims in carrying out their mission to carry out God's commands freely and responsibly. whereas the Qur'an has given freedom to choose their respective religions and beliefs, which may be in accordance with the word of Allah: There is no compulsion to (enter) religion (Islam); Verily, the right path has become clearer than the misguided path. (2:256).

In the reality of life there are so-called "religious people, there are also, he said, "nonreligious people." So how do you understand it properly and correctly? 
Substantially there are different incarnations between people who are really religious and people who pretend to be religious. These differences can be seen in several ways. The first is firmness of faith. The firmness of faith can be interpreted as "seriousness and sincerity in practicing religion" meaning that a person is "religious with the heart." The picture of a person's firm faith can be seen from his attitude and behavior. Attitudes can reflect a person whether he is a person who is firm in holding principles or someone who is easily influenced. While behavior can reflect a person's actions whether his actions lead to positive or negative things. A person who has firm faith will always strive that the life he is living should not conflict with religious teachings. In human experience, Faith will always have ups and downs. Harun Nasution said "Although Abu Hanifa said "Faith has no increasing or decreasing nature". The ups and downs of faith will describe whether a person is a person whose faith is firm or fragile. "There are not many people who are religious in this way, but most people believe in religion only" is not a religious person who is smart in religious theory, mastering Arabic feels that he has mastered Allah's knowledge in the Koran, if he is dressed and has Islamic attributes, it feels like he has perfect muslim, while he does not carry out orders and does not stay away from the prohibitions of Allah swt in the sense of commanding good and forbidding evil. Second, consistency in obeying religious teachings. There are some people who understand that they practice religious teachings in moderation, do not need to be too obedient and also do not often violate religious teachings. There are even people who pray, but the immorality goes on. This actually shows a person's inconsistency to God. The Qur'an teaches humans to consistently hold faith and carry out religious teachings properly. As He says: Verily, those who believe are those whose hearts tremble at the mention of Allah's name, and when His verses are recited their faith increases (because of it), and only in Allah they put their trust. (QS8:2)

A person is said to be a true religion (Islam) that can be proven by his faith. For example, it is like the situation of a person who is rowing a boat in the middle of the ocean with the waves and the waves are terrific and rumbling. Far away, it looks dim to the destination island. While in the middle of the ocean, there must be an uncertainty/doubt in the mind of the rower that raises a question mark: "Can you arrive at the island you are aiming for?" Well, so it is with faith! There will be various question marks in the minds of believers about the objects of their faith. This question mark will always appear before arriving at the destination island, that is, before the arrival of death. Thus the strand of Quraish Shihab in his book "Sowing Divine Messages".

By being consistent in religion, Allah will give a better reward for us, both in this world and in the hereafter. In religion there are also pillars that can provide an indicator of whether a person has been religious holistically, in the language of religion it is called kaffah (complete) or partial. Consistency in carrying out Allah's commands means having to "improve the quality of faith" meaning that one must learn, the way is up, can be with others, can be alone, learn formally or informally. The most important condition is in accordance with religious orders. The pillars in question are as follows: First, learning to know or knowledge (learning to know), Second, learning to do or charity (learning to practice), Third, learning to be or ihsan personally, Fourth,

It has been mentioned above about people who are consistently religious and religious people are just bad luck. If people do something by experimenting, testing, exploring various possibilities, first questioning, it is known as an act that is not religious, pragmatic and secular, even if it is done in an ordinary, relaxed, modest, even joking manner, it is not said to be a religious act, on the other hand if something is treated with special, very respectful, very orderly and solemn that is what is called the characteristics of a religious person. This is the opinion of Bustanuddin Agus in his book "Religion in Human Life" . It is no exaggeration to 
say that the major religions always teach their adherents to always obey the rules that have been determined, Confucianism and Buddhism are more of a collection of moral teachings than belief in God. Hinduism also teaches moral norms and relates to dharma nutmeg sanctions and reincarnation. Judaism emphasizes its moral and legal aspects more than spiritual aspects. Christianity emphasizes the spiritual aspect in instilling moral values. Islam teaches morals towards oneself, towards others, towards flora and fauna, as well as morality towards Allah and His Messenger. Those are the signs of people who differ between religious people and non-religious people, especially in Islam, the moral aspect is concreted into a legal aspect.

What are the core teachings of Islam? How to understand it and how to teach it to humans?

Talking about the core problems of Islamic teachings, this cannot be separated from the purpose of Allah creating Jin and Humans, namely to worship Him. All of this philosophically can provide an understanding of His monotheism. Therefore, to understand it, of course, it is necessary to be equipped with various kinds of knowledge, whether religious, social, cultural. Because Islam is not a static religion, but a dynamic religion, not a religion belonging to anyone, but belonging to everyone, not an inherited religion, but a religion from God, not human speech, but the word of God, not an artificial religion but a natural religion from God.

Broadly speaking, there are three kinds of core teachings of Islam. First, surrender to Allah by obeying Him. The essence of the first Islamic teachings is to surrender whole body and soul to Allah based on the purity of monotheism to him alone. "Submit" here means humiliating and humbling oneself accompanied by sincere submission of every servant to his creator. So that in its entirety it means that a servant surrenders, is obedient and submits to Allah to elevate His oneness in the rights of will and do what makes His oneness normal in the rights of worship.This is the essence of monotheism of Allah, which is called monotheism of worship, meaning that all worship of servants is shown to Him alone.

You know, uniting Allah with all worship is the most fundamental thing in Islamic teachings. The greatness of this worship is implied from its mention in the Book of Allah (alQur'an) and in the hadiths of the Prophet Muhammad. It is the first command of God and the initial call of His messengers to mankind, even the apostles were sent for the purpose of monotheism of worship.

Second is to realize obedience to Allah's commands and stay away from His prohibitions, why does Islam command humans to obey the commands of Allah and His Messenger, what benefits will those who obey, what is the harm if they do not obey? Questions like this may often cover the sacred nature of everyone who is reluctant to obey.

There is one thing that we must always remember, namely that Allah has sent messengers to all the people, there is not even a single people but Allah has sent them an apostle. Allah also mentioned the purpose of sending them to convey good news as well as warnings and threats. Allah says:

Verily We have sent you with the truth as a bearer of glad tidings and as a warner. and there is no people but there is in it a warner.(Surah Fathir: 24)

The good news and warnings are conveyed to all this people, namely good news for those who obey and warnings and threats for those who are reluctant. Know that whatever obedience is performed by humans is essentially for their own good and not to please Allah by obeying Him. Indeed, human obedience to Allah and His Messenger is a basic need because of their need for the mercy of Allah, the Creator. Therefore, Allah commands people 
to obey Him and obey His messenger, that is, so that they are blessed by the Lord of the worlds. These are some of the glad tidings brought by the apostles.

Thirdare: Breaking away from the elements of shirk and its perpetrators. The initial obligation for every Muslim is pure and sincere monotheism along with breaking free and washing hands from shirk. Pay attention to what Allah has commanded and from what He has forbidden us in the following verse:

Worship Allah and do not associate anything with Him... (Surat an-Nisa: 36) Here, Allah Almighty, commands His servants to worship Him and forbid them to associate with Him. This contains the determination of the right to worship only for Him alone. So whoever does not worship Him is an arrogant disbeliever, and whoever worships Allah with worship other than Him is an infidel and polytheist, while whoever worships Him alone is a sincere Muslim. You know, breaking away from shirk requires breaking away from the perpetrators. When a person tries to purify himself from shirk, his effort requires him to clean himself from good relations with the perpetrators of shirk over their shirk. Quraish Shihab says in his book Sowing Divine Messages: "Before the Prophet Muhammad saw. Teach how religious laws, he first introduced God to His beautiful attributes. He is the Sustainer, He is the Creator of the universe, and He is the Most Gracious. That is what was first introduced in the first revelation. Finally, may Allah guide us all to follow His straight path in a hanif religion according to His will.

As Muslims, to anticipate the mistakes made by these scholars, we must deepen our knowledge with the knowledge gained by reading verses in the Qur'an based on their interpretations if we cannot translate them directly from the language of the Qur'an. Because the Book of the Qur'an is absolutely true and there is no doubt in it when you read it, because Allah has guaranteed the authenticity and authenticity of the contents of the Qur'an, there is no human, including the jinn, who can influence your heart and mind so that your interpretation of things is distorted. Perverted thing and Allah says in His Word: "He sent down the Qur'an to you (Muhammad), which contains the truth, confirms the previous books, and sent down the Torah and the Gospel (Surah 3:3) "O mankind, the lesson of the Qur'an has come to you. Qur'an from your Lord, healing for the disease that is in the chest, and guidance and mercy for those who believe. (Surah Yunus: 57). So when we read it, we will get a lot of wisdom. It's different when we read a novel, once we read it after knowing the contents of the story, reading the next stage will still not change its contents. Whereas reading the Qur'an the first time it is read will be different from the wisdom obtained when reading the next and so on. So Allah said: "And if the tree branches were made into pens and the sea into ink and seven more seas were added after drying, surely Allah's words would never run out... (Surah Luqman: 27). So when we read it, we will get a lot of wisdom. It's different when we read a novel, once we read it after knowing the contents of the story, reading the next stage will still not change its contents. Whereas reading the Qur'an the first time it is read will be different from the wisdom obtained when reading the next and so on. So Allah said: "And if the branches of the trees were made into pens and the sea into ink and seven more seas were added after drying, surely Allah's words would not be exhausted.

Then Allah said: "And indeed, We have made in this Qur'an all kinds of parables for humans, so that they may learn." (Surah Al-Zumar: 27). So why are Muslims reluctant to read the interpretation so that they can learn a lesson? And most of them just read without understanding the contents that are read, as a result, the Qur'an is only as a complement and stored only and used only the traditions and opinions of the scholars. As a result, many young Muslims who are deepening their Islam are finally trapped in misleading schools and ideologies and have deviated far from the true teachings of Islam based on the Qur'an. The reason is because what is used as the basis of science is using the hadiths and opinions of the 
scholars without using the Qur'an at all. The Qur'an can only be read in Arabic without understanding its contents, because many scholars even consider it taboo to read its interpretation, it is enough just to read it and get the reward. That is why there are those who are desperate to commit suicide bombings to get martyred and consider it the same as Jihad and go to Heaven. On the contrary, those who do it do not go to heaven but fall into "Hell". What should be true is that what is learned and understood, the instructions are basically the Qur'an, while the hadiths are complementary to increase knowledge from what is obtained in the Qur'an. In fact, understanding Islam "must be learned from its original sources, namely the Qur'an and the Sunnah of the Prophet. Misunderstanding Islam,

Furthermore, how to teach humans about Islam, this of course must first understand the methods. In Islamic studies the method also means "Thariqah", which means strategic steps that are prepared to do a job. Thus the teaching method can be interpreted as a method used by teachers in teaching students during the learning process. The method implies a planned, systematic work sequence and is the result of scientific experiments in order to achieve the planned goals. The educational method is a science of the methods used in the work of educating. The origin of the word "method" contains the meaning of "a path taken to achieve a goal" "method in Arabic, While the educational methodology is "a science that talks about the path or way that must be passed to achieve educational goals or master certain competencies formulated in the syllabus of subjects". Thus, the methodology of Islamic studies is a way of studying and investigating Islam and its adherents, both since the time of the Prophet Muhammad, khulafaur Rasyidun, the classical period, the Middle Ages, even up to our time today. So that Islam, not a religion that is identical with backwardness, ignorance, even a threat that is considered dangerous, is considered a terrorist by adherents of other religions, especially America and its allies.

The phenomena or symptoms as mentioned above have been stated by Karen Armstrong, stating "We in the west have a long history of hatred and hostility towards Islam. However, hatred continues to be prominent and growing stronger around the Atlantic. Nothing can stop people from attacking Islam even though they don't know the slightest bit about it."

In this case, the Koran itself teaches how to use a good teaching method so that people will be happy and willing to accept its teachings, and non-Muslims will no longer hate its adherents. Allah SWT. Has given to the prophet Muhammad saw. Tariqah guides the people according to His word, which means: "Call (people) to the way of your Lord with wisdom and good lessons and refute them in a good way. Verily, it is your Lord who knows best who has strayed from His path, and it is He who knows best those who are guided." (QS16:125)

In Al-Maraghi's commentary, it is explained that Prophet Muhammad SAW is recommended to imitate Prophet Ibrahim who had noble qualities, who had reached the peak of high degrees of dignity in conveying his message. Allah said: Then we revealed to you (Muhammad): "Follow the religion of Abraham, a hanif." and he is not one of those who associate partners with God (Qur'an 16:123)

The method mentioned is with wisdom, namely with the Qur'an. The general meaning of this verse is that the Prophet was ordered to invite his people in ways that have been guided by the Qur'an, namely by means of al-Hikmah, Mau'izhah Hasanah, and Mujdah. In this way the Prophet as an Apostle has succeeded in educating his people with full awareness. This incident was experienced by the Prophet himself when the Quraysh tortured him "they became thinking and studying the truth of the teachings brought by Muhammad. Because if it were not for the belief of the missionaries in the truth of the message they profess, surely they would not be so strong when facing various attacks and confrontations." 
Azyumardi Azra said in his book Islamic Education, Tradition and Modernization towards the New Millennium "The Prophet Muhammad saw. Both when he was in Mecca, and after moving to Medina, he perfectly showed his example as the main educator. In Mecca, his main mission was to build a monotheistic society; lays the fundamental foundations for the formation of a viable historical community nucleus to respond to the challenges of the times." This shows the procedure for inviting people to accept and practice Islam slowly but surely. Meanwhile, in Medina the Prophet as the main educator in the development of the socio-political society-political-religious Islamic society of Medina.

There are four kinds of Islam that provide a pattern of family development. The family is the basis of the ummah (nation); and because of that the condition of the family determines the condition of the ummah itself. As Azyumardi Azra said in his book "The New Paradigm of National Education" "First: a family that has the passion and love to learn and live religious teachings. Second; a family where every member respects and loves each other. Third; family in terms of living is not excessive. Fourth; families who are aware of their weaknesses and shortcomings; and therefore always tries to improve the knowledge and knowledge of every member of his family through a lifelong learning and education process. Thus, if the community has carried out such an educational process,

When Islam before the 1970s there was a trend of being perceived as "ignorance" and "backwardness," then now there is also a trend of Islam being seen as a threat." Where did it go wrong? What causes it, and how to get rid of it?

The trend of ignorance and backwardness even as a threat to Islam is a wrong opinion even wrong. because the arrival of the prophet Muhammad SAW to this earth is as rahmatan lil'alamin, as the word of God which means:

And we have not sent you except to be a mercy to the worlds (Surah 21:107)

Even the Messenger of Allah said which means: Islam is high, and there is no religion higher than Islam. This hadith is corroborated by the word of Allah swt in the letter Ali Imran which means:

Verily, the only religion with Allah is Islam. There is no difference between those who have been given the Book except after knowledge has come to them, because of the envy (that exists) between them. whoever disbelieves in the signs of Allah, then surely Allah is swift in reckoning.(QS3:19)

This verse provides an understanding that Islam is the only religion that is most loved and loved by Allah swt, in the sense that all other religions will not be accepted by Him. Therefore, do not look at Islam in a traditional way, but more importantly see Islam rationally, so that the understanding of Islam is no longer wrong and considers it a religion that is identical with ignorance, backwardness and even a threat, once again this is a mistake. Whereas the position of Islam towards other religions is twofold, namely "accommodative and persuasive". This means that Islam accommodates the spiritual values found in past religions by providing new assumptions, passions and passions, such as their customs and habits of worshiping by slaughtering animals to be offered to the gods and the spirits of their ancestors who are considered as a form of seeking blessings.

Therefore, understanding Islam is not only partial, but must be comprehensive, so that Islam and its adherents do not become a trend that is synonymous with ignorance, even a threat in the midst of the current era of globalization.

The meaning of Islam cannot be separated from its education, meaning that Islam teaches its adherents to always hold fast to the original source to give birth to a comprehensive personality of its adherents. Azra quoted a result of the first international 
conference on Islamic education in Makkak in 1977, "Education aims at achieving the growth of a comprehensive human personality in a balanced way through the exercise of the soul, intellect, rational human self, feelings and senses. Therefore education must include human growth in all its aspects: spiritual, intellectual, imaginative, physical, scientific, language both individually and collectively, and encourage all these aspects towards goodness and achieving perfection.

This proves that Islam really expects its people to be smart, clever, skilled, both spiritually and intellectually, so that its adherents are required to learn various kinds of science and knowledge so that they can rise from adversity, destruction, backwardness, ignorance, and even be considered a threat to adherents. other religions. In line with that, Muslims must have "a sincere spirit of mutual respect and true mutual respect is the basis for the existence of human association in a democratic social and political system" . "A Washington Post/ABC News poll in 2006 found that nearly half of Americans (46\%) have a negative view of Islam - the proportion of Americans who believe Islam helps increase violence against non-Muslims has more than doubled since the September 11 attacks, from 14\% in January 2002 to 33\% - Pew Research Center found that about a third of Americans say Islam has more potential than other religions to encourage violence among adherents" Then the author assumes as Azra hints "the absence of democratic culture is the next factor that hinders democracy in Muslim countries. The strong traditionalism of Islamic politics which is displayed by some kiyai (ulama) and then practiced by some people in Indonesia, for example, is one of the obstacles to the emergence of a democratic culture in Indonesia which is followed by a weak or dysfunctional civil society." Thus, education about Islam is no longer synonymous with ignorance, backwardness and a threat to its adherents.

\section{Conclusion}

The study approach of al-The Qur'an has recently penetrated intovarious perspectives and analyzes, no longer using only one theological-normative perspective, but using various modern perspectives.Qureân, or better known asIth Tafsir Science, is one of the (Islamic) sciences that is experiencing very fast development, even faster when compared to other scientific methods, such as the study method of hadith and usufructuary. $\} 1$ al-fiqh (istinbat method \} law). For this reason, the provision of courses in al-Qureân with the classical scientific system, namely the separation of between Ulm al-Qur'ên and the Science of Tafsir, which are presented partially will cause students to miss the development of al- Quran.

Another thing that supports the urgency of developing al-Qureânis the priority of alQureân as a paradigm of thinking(manhaj al-fikr). The offer of a paradigm as an alternative paradigm is a response to epistemological imperialism which is more influenced by rationalism and empiricism in the scientific method.

The last thing mentioned in its development has resulted in modern science, specifically Western science, receiving sharp criticism from many experts who regard Western science as the main factor in the collapse of human values because it separates humans from nature and breaks the value of the branches of knowledge. Answering it all, the study of al-Qureân cannot be presented withonly uses one paradigm, but must be multi-paradigm, in accordance with the meaning of al-Multi-Quran-sided and multi-dimensional. Thus, scientific studies of al-The current Qurâncarried out in a partial scientific system, must be changed by using a paradigm and a holistic approach, namely an approach that makes the scientific study of alQur'ân in an integrated unit, to avoid the most negative impact of the effects of al-Partial Qur'an. 


\section{References}

Abdullahi Ahmed An-Na'im, Islam dan Negara Sekuler

Abuddin Nata. (2010). Metologi Studin Islam, Jakarta: PT RadjaGrafindo Persada.

Azyumardi Azra. (2006). Paradigma Baru Pendidikan Nasional, (PT. Kompas Media Nusantara, Cet. Ke. 2)

Azyumardi Azra. (1999). PENDIDIKAN ISLAM Tradisi dan Modernisasi Menuju Milenium Baru, Cet. Pertama (PT. Logos Wacana Ilmu)

Bustanuddin Agus. (2007). Agama dalam kehidupan Manusia, (PT. Raja Grafindo Persada, Jakarta)

Hasbullah, et al. (2019). Messages Communication in the Al-Qur'an (Study of Messages in the Al-Qur'an for Believers). Budapest International Research and Critics InstituteJournal (BIRCI-Journal). P. 125-131.

Harun Nasution. (1998). Islam Rasional, (Penerbit, Mizan, Cet. Ke. V)

Harun Nasution. (2011). Teologi Islam, (Universitas Indonesia, UI-Press)

Imam Abi Husain bin Hajjaj Qusairi An Naisaburi, Sahih Muslim, Juz. IV, ( Bairut. Dar AlFkr, tt,)

Irena Handono. (2008). Menyingkap Fitnah Teror, (Gerbang Publising, Cet. Ke-I)

Jonh L. Esposito dan Dalia Mogahed. (2008). Saatnya Muslim Bicara, Terjemahan Eva Y. Nukman, (PT. Mizan Pustaka, Cet, Ke-II)

Juhaya S. Praja, Tiori Hukum dan Aplikasinya, h. 227-228)

M. Quraish Shihab. (2006). Menabur Pesan Ilahi, (Lentera Hati, Cet. Ke-II)

Nurcholish Madjid, et al. (2004). Fiqih Lintas Agama, (Yayasan Wakaf PARAMADINA)

Nurcholish Madjid. (2008). Islam Kemordenan dan Keindonesiaan, (PT. Mizan Pustaka, Cet - I)

Nurcholish Madjid. (2003). Jejak Pemikiran dari Pembaharu sampai Guru Bangsa, Cet. II ( Pustaka Pelajar)

Ramayulis. (2008). Metodologi Pendidikan Islam, (Kalam Mulia, Cet. Kelima) 